\title{
$\mathrm{PLC}$ 를 이용하여 케적절단과 동시에 용접부 개선이 가능한 자동 3 축 파이프 형상절단 시스템 개발
}

노태정 ${ }^{* *}$, 김화일 ${ }^{1}$

${ }^{1}$ 동명대학교 메카트로닉스공학과

\section{Development of Automatic 3-Axis Pipe Profile-Cutting System with Bevelling of Welds Using PLC}

\author{
Tae-Jung Lho ${ }^{1^{*}}$ and Hwa-Il Kim ${ }^{1}$ \\ ${ }^{1}$ Department of Mechatronics Engineering, Tongmyong University
}

\begin{abstract}
요 약 3축 파이프 형상절단기에서 다양한 접합형상에 대하여 모관과 지관의 접합궤적을 수학적으로 유도하였다. 그 접합궤적에 절단폭 등의 공구 보정하여 실제로 가공할 절단궤적을 결정하여 이 공구궤적에 해당하는 CL-data를 생성하고, 또한 공구 궤적을 확인하기 위하여 ghost 기능을 구현하였다. 생성된 CL data를 PLC의 위치결정제어 모듈 에 로딩하여 동시 3축 $(\alpha, X, \beta$ 축)의 이송을 제어하여 경로를 따라서 형상절단과 동시에 개선을 할 수 있도록 동시 3축 파이프 형상절단 시스템을 개발하였다.
\end{abstract}

\begin{abstract}
Joint paths of master and branch pipes are induced mathematically for many kinds of joint patterns between both pipes in 3-axis pipe profile-cutting machines. By compensating them with a kerf width, the real cutting paths are determined, and their CL-data are generated, and the tool paths generated by CL-data are verified by a ghost function. A bevelling of welds is implemented through tilting a cutting torch in the $\beta$-axis direction for 8 sections in the chuck rotation of $a$-axis. A PLC controls simultaneously position and velocity in a real time for $\alpha, X, \beta$-axis by loading CL-data generated. We developed the PLC-controlled 3-axis pipe profile-cutting system which can cut a master or branch pipe along the cutting path and simultaneously do a bevelling process.
\end{abstract}

Key Words : Master Pipe, Branch Pipe, Joint Pattern, PLC, 3-axis Pipe Profile-Cutting Machine, Joint Path, Cutting Path, Bevelling, CL-data, Ghost

\section{1. 서론}

육상 트러스 구조물, 조선, 해양 구조물 및 배관 등의 산업분야에 다양한 용도로 사용되고 있는 파이프의 접합 형상에 따른 용접을 하기 위하여 파이프를 대부분 수작 업으로 절단하고 있다. 대부분의 파이프 가공 형태는 평 판 절단과 다르게 곡면에 대한 절단이 이루어져야하므로 작업자가 필요한 형상이 전개된 두꺼운 백상지를 활용하 여 파이프에 석필로 절단 형상 및 길이 표식 후 표시된 라인을 따라 작업자가 직접 절단기로 작업을 하고 있다.
또한 수작업으로 파이프를 절단할 시에는 상당한 시간과 작업자의 숙련된 기술이 필요하다. 특히 수가공시 해양 플랜트, 열교환기 등의 복잡하게 조립되는 가공물에 사용 되는데 하중을 지지하는 역할이나 내부에 매질이 흘러가 는 파이프의 특성상 불량품이 가공물에 조립될 경우 그 가공물은 강도나 성능의 신뢰성을 확보하기 힘들다고 할 수 있다[1,2].

그리고 일반적인 파이프 절단기로 절단가공을 하였을 경우 후 공정인 파이프 접합 용접을 위하여 개선 (bevelling)을 위한 후가공이 필요한데, 특히 플라즈마나

\section{본 논문은 중기청의 산학공동기술개발사업과 지경부의 지역산업기술개발사업의 일부 연구비 지원으로 수행되었음.} "교신저자 : 노태정(tjlho@tu.ac.kr)

접수일 09년 8월 24일수정일 09년 11월 04일 게재확정일 09년 11월 12일 
산소를 이용하여 1 차 가공을 하게 되면 절단면에 가공경 화가 발생하여 개선작업을 수행하는데 상당한 애로사항 이 발생하므로, 궤적 절단과 개선을 동시에 가공할 필요 가 있다.

연구적 배경으로서, [3]은 파이프 코스터(pipe coaster) 를 이용한 파이프 트러스의 자동제작시스템을 개발하였 으며, [4]는 자석식 자동 파이프 절단기를 위한 신뢰성 있 는 제어기 개발하였으며, [5]는 레이저 5축 경사절단기 및 궤적생성 알고리즘을 개발하여 임의형상을 가공하는 데 적용하였으며, [6]는 상용 $\mathrm{CAD} / \mathrm{CAM}$ 을 활용한 정밀 부품 가공에 대하여 연구하였으며, [7]는 워터젯에서 천 연 가죽 같은 비정형의 원단에 최적 배치를 고려한 $\mathrm{NC}$ 코드 생성 및 경로확인이 가능한 $\mathrm{CAM}$ 시스템을 개발하 였고, [8]은 5축 레이저 절단기를 이용한 파이프 절단용 $\mathrm{CAM}$ 시스템을 개발하였으며, 또한 [1]과 [9]는 파이프 접 합형상에 따른 절단궤적을 수학적으로 유도하여 $\mathrm{NC}$ 코드 를 생성하고 그 경로를 확인하는 $\mathrm{CAM}$ 프로그램을 개발 하여 이를 6축 $\mathrm{CNC}$ 파이프 코스터에 적용하였으며, [2] 는 파이프 접합형상에 따른 지관 제작용 자동 파이프절 단기 개발에 관한 연구가 이루어졌다.

이에 대하여 본 논문에서는 각종 파이프 접합형상에 대하여 주로 지관을 제작할 수 있도록 기구부를 4축 이송 구조로 간단하게 구성하였고, 또한 PLC를 이용하여 궤적 절단(profile-cutting)과 개선이 동시에 가능하도록 자동 3 축 파이프 형상절단기를 개발하여 신뢰성을 제고하였으 며, 터치패널을 활용하여 가공 상태를 실시간을 모니터링 하고 작업자가 작업이 용이하도록 기능을 단순화하였다.

\section{2. 파이프 절단기 기계부 설계.제작}

자동 파이프 형상절단 시스템은 크게 기구부, PLC 제 어 및 전장 패널, 그리고 CAM 프로그램이 내장된 터치 패널로 구성된다.

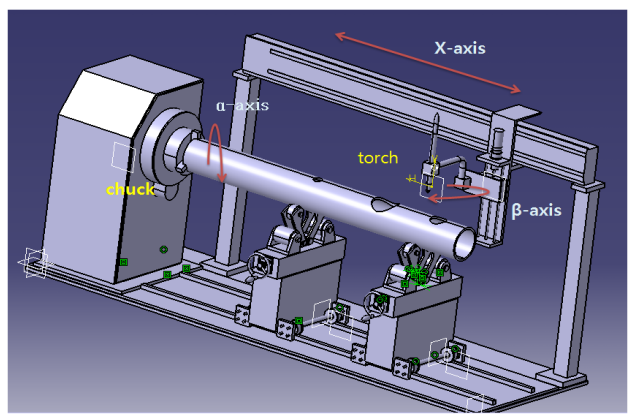

[그림 1] 파이프 형상절단기 기구부의 3D Modelling
그림1은 기구부의 구조설계 및 동작 시뮬레이션을 위 하여 Catia를 이용한 3D 모델링한 결과이다.

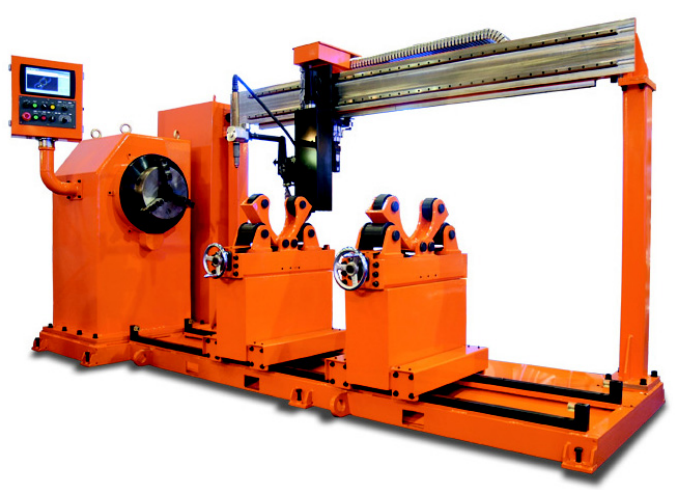

[그림 2] 파이프 형상절단기 시제품 외관

그림2는 기구부의 구조설계 및 동작 시뮬레이션을 바 탕으로 실제로 설계.제작한 자동 3축 파이프 형상 절단기 의 외관을 나타낸 것이다.

\section{3. 절단궤적과 개선 알고리즘}

산업현장에서 주로 사용되는 모관(master pipe)과 지관 (branch pipe)의 접합형상(joint pattern)들을 선정하여 각 각의 형상에 대한 모관과 지관의 접합궤적(joint path)을 유도하였다[9].

그림3에서 보는바와 같이, 기구부는 총 4개의 이송축 으로서 척(chuck)을 구동하는 $\alpha$ 축, 겐트리를 구동하는 $X$ 축, 가공물에 용접을 위한 개선을 할 수 있도록 토치를 틸팅(tilting)하는 $\beta$ 축, 그리고 가공 전 토치 위치를 설정 하는 $Z$ 축으로 구성된다.

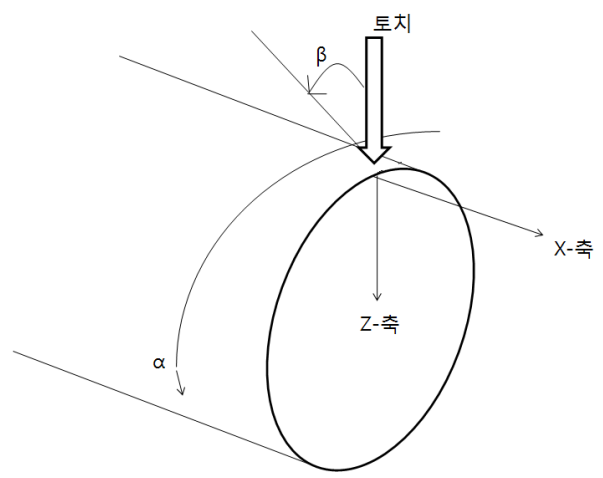

[그림 3] 파이프 절단기의 이송축 
수직교차접합은 모관과 지관이 수직으로 교차하여 만 나는 형상으로서, 그 접합궤적을 구하기 위하여 정사영법 을 통하여 각 궤적의 $\alpha, X$ 축의 좌표 값을 구현하였다. 수직교차접합에서 모관의 접합궤적, $X_{M}$ 은 모관의 수직하 방에서 볼 때 $\mathrm{XY}$ 평면에서 1 회전하는 동안 $X$ 축이 식(1)의 궤적을 따라서 이동하면서 형성된다.

$$
X_{M}=\frac{\phi_{B}}{2} \cos \theta
$$

여기서 $\Phi_{B,} \theta$ 는 각각 지관의 외경 및 모관의 $\mathrm{XY}$ 평면 에서의 회전각도이다.

수직교차접합에서 지관의 접합궤적, $X_{B}$ 는 척인 $\alpha$ 축이 1 회전하는 동안 $X$ 축이 식(2)의 궤적을 따라서 이송하면 서 형성된다.

$$
X_{B}=-\left[\frac{\phi_{M}}{2}-\left\{\frac{\phi_{M}}{2} \cos \left(\sin ^{-1}\left(\frac{\phi_{B} \sin \alpha}{\phi_{M}}\right)\right)\right\}\right]
$$

여기서 $\Phi_{M}, \Phi_{B}, \alpha$ 는 각각 모관의 외경, 지관의 외경 및 회전하는 척의 회전각도이다.

사선교차접합은 모관과 지관이 접합경사각 $\delta$ 만큼 경 사지게 접합되는 형태로서, 모관의 접합궤적, $X_{M}$ 은 모관 의 수직하방에서 볼 때 $\mathrm{XY}$ 평면에서 1 회전하는 동안 $X$ 축 이 식(3)의 궤적을 따라서 이동하면서 형성된다.

$$
X_{M}=\left(\frac{\phi_{B}}{2} \cos \theta\right) \pm\left|\frac{\phi_{B}}{2} \tan \left(45^{\circ}-\frac{\delta}{2}\right) \cos \theta\right|
$$

사선교차접합에서 지관의 접합궤적 $X_{B}$ 는 회전축인 $\alpha$ 축이 $0^{\circ} \sim 360^{\circ}$ 로 1 회전할 때 각각 $\mathrm{X}$ 축이 식(4)의 궤적을 따라서 이동하면서 형성된다.

$$
\begin{aligned}
X_{B}= & -\left[\frac{\phi_{M}}{2}-\left\{\frac{\phi_{M}}{2} \cos \left(\sin ^{-1}\left(\frac{\phi_{B} \sin \alpha}{\phi_{M}}\right)\right)\right\}\right] \\
& \pm\left\{\frac{\phi_{B}}{2} \tan \left(45^{\circ}-\frac{\delta}{2}\right) \cos \alpha\right\}
\end{aligned}
$$

모관의 사각절단은 한쪽의 면을 가공하기 위해서 움직 이는 1 개의 직선축 또는 회전축을 제외한 나머지 축은 정 지한 상태로 대기하는 방식이다. 따라서 $\alpha$ 축과 $X$ 축 이 송은 식(5)와 같다.

$$
X_{M}=L
$$

$$
\alpha=\sin ^{-1}\left(\frac{W}{\frac{\phi_{M}}{2}}\right)
$$

여기서 $L$ 은 절단 사각형의 $X$ 방향으로의 길이이고, $W$ 는 절단 사각형의 폭이다.

그림4와 같이 평면 접합은 평판인 모관과 파이프 지관 이 경사각 $\delta$ 만큼 경사지게 접합되는 형태로서, 지관의 접합궤적 $X_{B}$ 는 $\alpha$ 축이 1 회전할 때 $\mathrm{X}$ 축이 식(6)의 궤적을 따라서 이동하면서 형성된다.

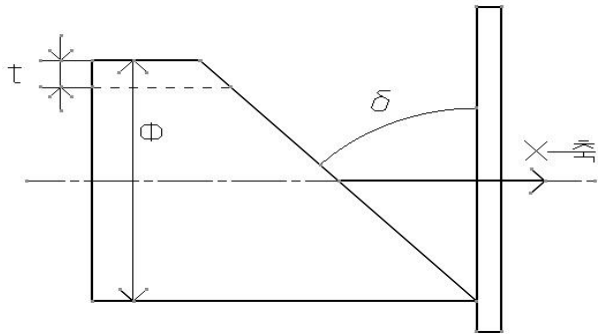

[그림 4] 평판과 지관의 평면 접합

$$
X_{B}=-\left\{\phi_{B}\left(\frac{\tan \delta}{2}\right) \cos \alpha\right\}
$$

그림 5 는 지관의 외경 $100 \mathrm{~mm}$, 경사각 $\delta=45^{\circ}$ 의 평 면절단에 대하여 지관의 회전 각도 $\alpha$ 에 대한 $X$ 축의 궤 적, 식(6)을 Matlab으로 시뮬레이션한 결과이다.

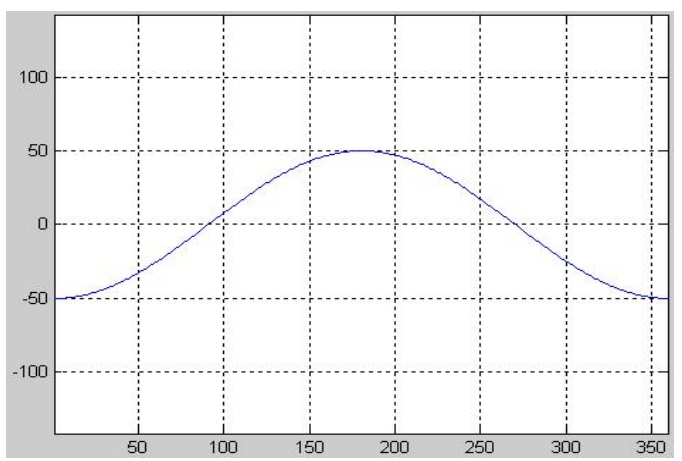

[그림 5] 사각절단의 Matlab 시뮬레이션 결과

각종 접합형상에서 모관의 절단궤적(cutting path)은 모관의 접합궤적에 후공정인 용접을 원활하게 하기 위하 여 절단폭(kerf width) $W_{c}$ 를 고려하여 지관의 외경을 아 래의 식(7)과 같이 대체해야한다.[7] 


$$
\Phi_{B}<-\Phi_{B}-W_{c} / 2
$$

또한 지관의 실제적인 절단궤적은 지관의 접합궤적에 절단폭을 고려하여 지관의 $X$ 축 좌표를 아래의 식(8)과 같 이 대체해야한다.[7]

$$
X_{B}<-X_{B}+W_{d} / 2
$$

개선은 절단 된 파이프를 용접할 때 보다 용이한 용접 을 위한 접합 부분에 틈을 만들어 용제가 잘 들어갈 수 있도록 하여 파이프의 모관과 지관의 접합시 용접작업의 편의성과 접합강도를 높일 수 있다.

그림6과 같이, 파이프의 원주방향으로 $45^{\circ}$ 씩 8 개 회 전각도에 대하여 사용자가 개선 각도를 입력을 한다. 따 라서 $45^{\circ}$ 정수배 사이의 임의의 각도에 대하여는 8 개 각 도의 개선각 입력 값들의 보간으로 해당 개선각을 구한 다.[9]

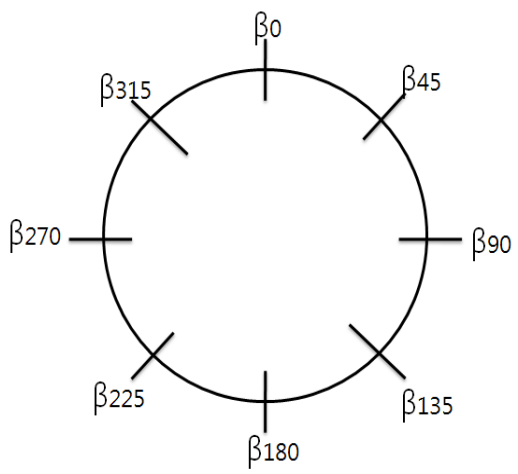

[그림 6] 8개 회전각도별 개선각 입력

\section{Operation Touch Panel 개발}

$\mathrm{CAM}$ 프로그램은 작업자가 모관과 지관의 접합형상 을 선정하고 각종 파라미터를 입력하면 자동으로 토치의 절단궤적, 즉 공구 궤적(tool path)인 CL-data[8]을 생성한 다. 또한 이 생성된 CL-Data에 대하여 실제로 가공하기 전에 ghost 기능을 통하여 절단하고자 하는 경로를 가상 으로 확인할 수 있도록 한다.

본 논문에서 연구한 파이프의 절단궤적을 기반으로 하 여 개발한 $\mathrm{CAM}$ 프로그램을 터치패널에 내장하였다. 그 림7은 자체적으로 개발한 터치패널의 주 화면으로서 툴 이송 좌표값, 각종 작업 상태, 현재의 가공 궤적 등이 실 시간으로 표시된다.

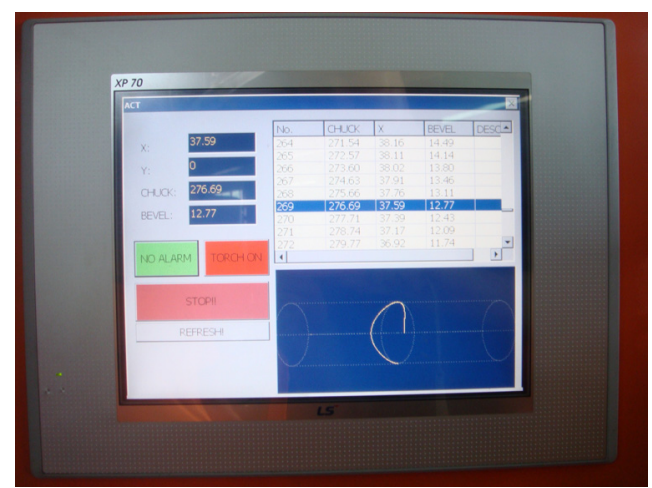

[그림 7] Operation Touch Panel의 주화면

그림8의 파이프 접합형상 선택 화면에서 작업자가 원 하는 형상을 선정하고, 다음을 누르게 되면 보다 정밀한 가공을 위한 설정값을 입력할 수 있는 그림9의 파이프 절 단 설정창이 나타난다. 기본 파라미터 설정에는 가공속 도, 진입선길이, 파이프 직경 및 두께, 조그 $(\mathrm{Jog})$ 이송속 도, 오버컷(overcut) 등을 설정할 수 있다.

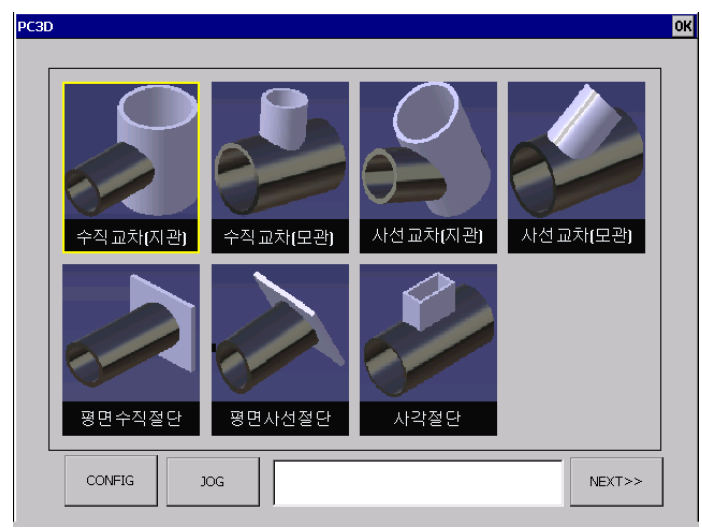

[그림 8] 파이프의 접합형상 선택 화면

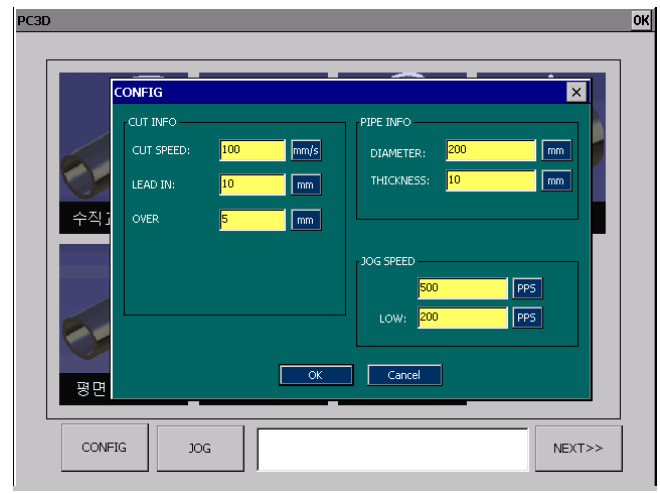

[그림 9] 절단가공의 기본 파라미터 입력 
진입선 길이는 플라즈마 토치가 최초로 $\mathrm{ON}$ 되는 지점 으로 최초로 플라즈마를 켤 때 발생하는 절단폭 보다 넓 은 피어싱(piercing)을 가공품의 품질에 손상이 가지 않도 록 하기 위함이다.

오버컷은 절단의 소재가 되는 파이프를 가공할 때 + 허 용오차로 인하여 지관 절단시 완전히 절단하지 못하는 경우가 발생하게 되는데 이를 방지하기 위하여 정해진 절단경로를 따라 입력된 값만큼 추가로 가공하여 절단이 완전히 이루어지도록 하는 기능이다.

그림 10 은 파라미터 값을 설정하는 창을 나타낸 것으 로서 실제 산업현장에서는 키보드나 마우스를 이용할 수 없으므로 터치 패널로서 입력이 가능하도록 하였다.

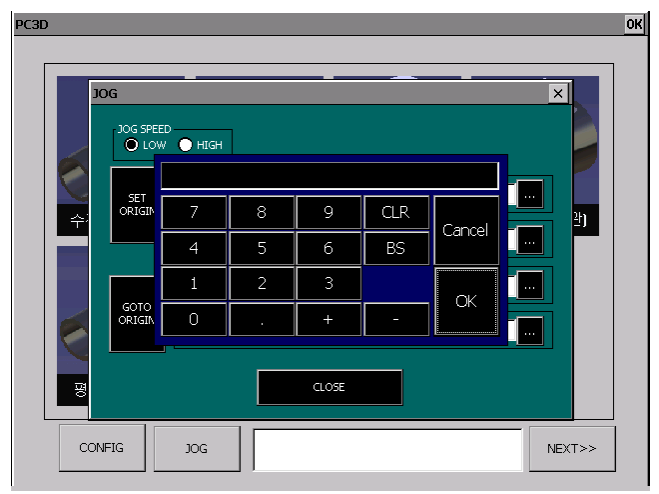

[그림 10] 파라미터 값 입력창

가공을 시작하기 위해서는 가공을 시작하고자하는 위 치를 조그이송과 인칭이송을 통하여 가공시작 지점을 찾 는 작업할 때의 창을 그림11에 나타냈다. 가공의 시작하 는 지점으로 이동이 완료되었을 시에는 "SET ORIGIN" 이라는 버튼을 누르게 되면 가공시작 원점을 설정하게 된다. 가공이 끝나고 다시 가공 시작지점으로 복귀 시에 는 "GOTO ORIGIN"을 누르면 그 위치로 이동하게 된다.

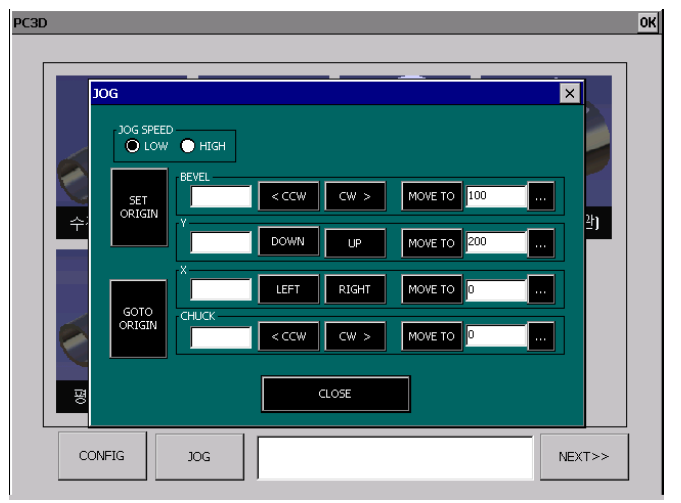

[그림 11] 조그운전 및 원점 설정
터치패널에 사용자의 가공하고자하는 파라미터 값을 입력 받아서 컨트롤러인 PLC의 CPU로 485통신으로 송 신한다. 그리고 현재의 가공속도, 가공정도, 정밀도 등을 실시간으로 모니터링이 가능하며, 또한 ghost 기능으로 실제 가공하지 않아도 가공된 파이프의 접합형태를 확인 이 가능하다.

\section{PLC의 Motion 제어기 개발}

그림12에서 보는바와 같이, PLC의 위치결정제어모듈 은 터치패널에 내장된 소프트웨어에서 생성된 절단궤적, 즉 CL data를 RS-485통신을 통하여 수신 받아서 축을 이 송하는 $\mathrm{AC}$ 서보모터를 구동할 수 있도록 드라이버에 펄 스형태의 구동 값을 전송하여 실시간으로 동시 3축의 속 도와 위치를 제어한다. 이때 각 이송축의 현재 속도 및 위치는 엔코더를 통해 모터 드라이브로 피드백 된다. 따 라서 PLC의 동시 3축 위치결정제어는 미소 구간의 직선 보간으로 궤적을 따라 입력한 절단속도로 각 이송축을 제어하여 파이프를 절단한다.

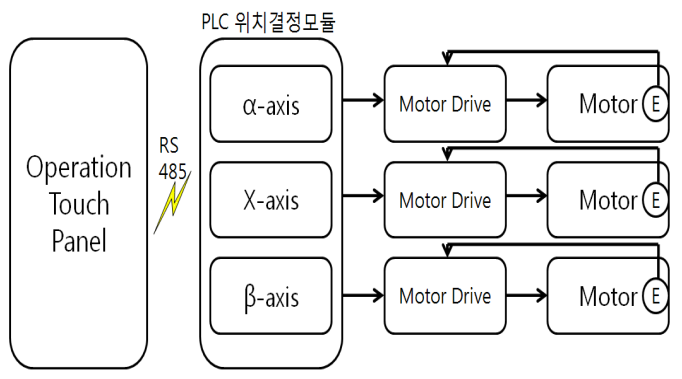

[그림 12] PLC 이용한 동시 3축 궤적제어 구성도

PLC는 LS산전(주)의 GM6-CPUB를 선택하였으며 I/O 모듈은 G6I-D24A, G6Q-RY2A, G6Q-TR4A를 선정하였 고, 위치결정제어모듈에서 $\alpha, X, \beta$ 3축 동시제어 위한 G6F-PP3D를 선정하였고(표1 참조), 파이프의 높이만 단 독으로 제어하는 Z축은 G6F-PP1D로 선정하였다.

[표 1] PLC의 위치결정모듈(G6F-PP3D) 사양

\begin{tabular}{|c|c|}
\hline 항 목 & 사 양 \\
\hline 제어축수 & 3축 \\
\hline 출력형태 & 펄스출력형 \\
\hline 보간 운전 & 2/3축 직선보간, 2축 원호보간 \\
\hline $\begin{array}{c}\text { 속도제어(위치제 } \\
\text { 어) }\end{array}$ & 가능 \\
\hline
\end{tabular}




\begin{tabular}{|c|c|c|}
\hline \multirow{2}{*}{$\begin{array}{c}\text { 위치제 } \\
\text { 어데이 } \\
\text { 터 }\end{array}$} & 용량 & 400개/축 \\
\hline & S/W & $\begin{array}{c}\text { APM소프트웨어 패키지 } \\
\text { (2000, XP지원) }\end{array}$ \\
\hline \multicolumn{2}{|c|}{ 설정단위 } & $\mathrm{mm}$, inch, degree, pulse \\
\hline \multicolumn{2}{|c|}{ 데이터 백업 } & Flash Memory \\
\hline \multicolumn{2}{|c|}{ 위치결정 범위 } & $-2,147,483,648 \sim+2,147,483,647$ \\
\hline \multirow{4}{*}{\multicolumn{2}{|c|}{ 속도 지령 범위 }} & $0.1 \sim 6,000.00(\mathrm{~mm} / \mathrm{min})$ \\
\hline & & $0.01 \sim 6,000.00(\mathrm{inch} / \mathrm{min})$ \\
\hline & & $0.01 \sim 6,000.00$ (degree/min) \\
\hline & & $1 \sim 1,000,000$ (pulse/sec) \\
\hline \multicolumn{2}{|c|}{ 최대 출력 펄스 } & $1 \mathrm{Mpps}$ \\
\hline \multicolumn{2}{|c|}{ 접속 거리 } & $10 \mathrm{~m}$ \\
\hline \multicolumn{2}{|c|}{ 가감속 패턴 } & 사다리꼴, $\mathrm{S}$ 자 형식 \\
\hline \multicolumn{2}{|c|}{ 가감속 시간 } & $1 \sim 65,535 \mathrm{~ms}$ \\
\hline \multicolumn{2}{|c|}{ 원점복귀 방식 } & 근시원점, 원점(Z상), 상/하한 신호 \\
\hline \multicolumn{2}{|c|}{ 고속원점 복귀 } & 가능(프로그램 원점) \\
\hline \multicolumn{2}{|c|}{ 수동 운전 } & JOG운전, MPG운전, 인칭운전 \\
\hline \multicolumn{2}{|c|}{ M코드 } & $1-65,535$ \\
\hline \multicolumn{2}{|c|}{ 동기 운전 } & 가능(주축, 외부 펄스입력) \\
\hline \multicolumn{2}{|c|}{ 백래쉬 보정 } & 가능 \\
\hline \multirow{2}{*}{\multicolumn{2}{|c|}{ 기타 }} & $\begin{array}{l}\text { 직접기동/간접기동, 속도변경, } \\
\text { 위치변경, 속도/위치전환 }\end{array}$ \\
\hline & & Zone출력, 동시기동 \\
\hline \multirow{2}{*}{\multicolumn{2}{|c|}{$\begin{array}{l}\text { 내부 소비전류 } \\
\text { (DC5V) }\end{array}$}} & $740 \mathrm{~mA}$ \\
\hline & & $840 \mathrm{~mA}$ \\
\hline
\end{tabular}

여기서 PLC의 위치결정제어모듈은 최대 400개의 스 텝을 가지므로 척이 1 회전하면 가공이 완료되는데, 즉 $360^{\circ}$ 를 400 등분을 하여 등분된 400 개의 좌표를 생성한 다. 이 400 개의 좌표형태는 척의 회전각도 $\alpha$ 와 $X$ 축의 이 동거리로 나오게 되는데, 각각의 좌표에 개선 각도를 입 력하여 가공에 필요한 400 개의 스텝을 만든다. PLC에서 스텝입력이 완료되면 위치결정제어모듈로 전송하여 각 이송축의 모터드라이브로 펄스신호를 보내어 미소 구간 의 직선보간을 계속 수행한다.

\section{6. 개발시스템의 적용}

모관과 지관의 외경이 같은 $125 \mathrm{~mm}$ 로서 수직교차접합 의 경우, 지관의 궤적절단과 개선 가공을 개발 시스템에 적용하여 검증하고저 하며, 우선 그림 13 는 지관의 접합 궤적에 대한 시뮬레이션 결과이다.

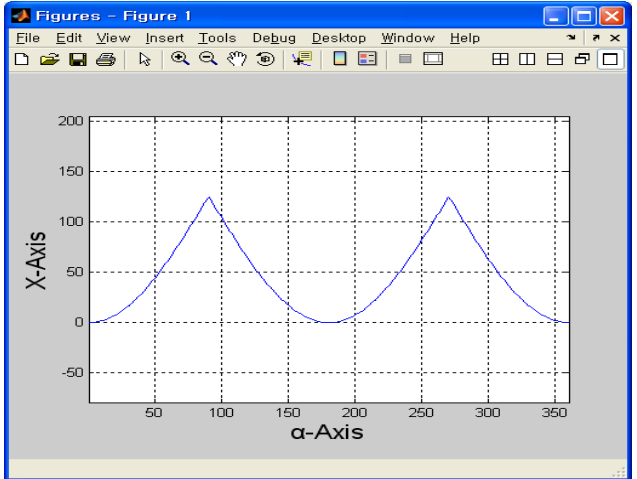

[그림 13] 수직교차절단의 지관의 접합궤적에 대한 Matlab 시뮬레이션 결과

그림14에서와 같이 파라미터 값과 "Auto Bevel”을 선 택하면 절단궤적과 개선각을 결정하며, 그림 15 와 같이 생성된 절단궤적, 즉 CL-data에 대하여 ghost 기능을 통 하여 가공 전에 예상되는 절단궤적을 확인할 수 있었다.

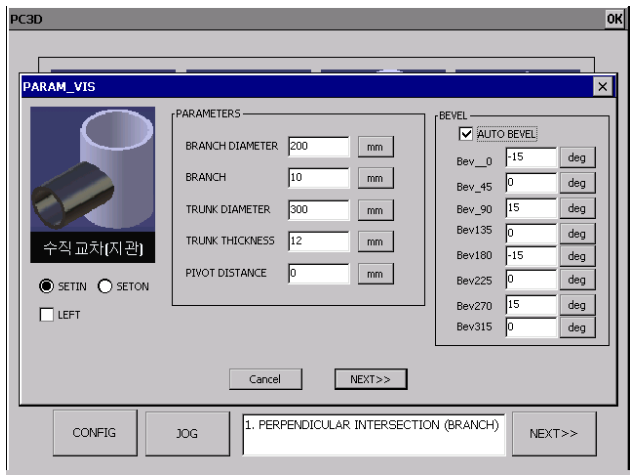

[그림 14] 수직교차절단(지관) 가공시 파라미터 입 력 화면

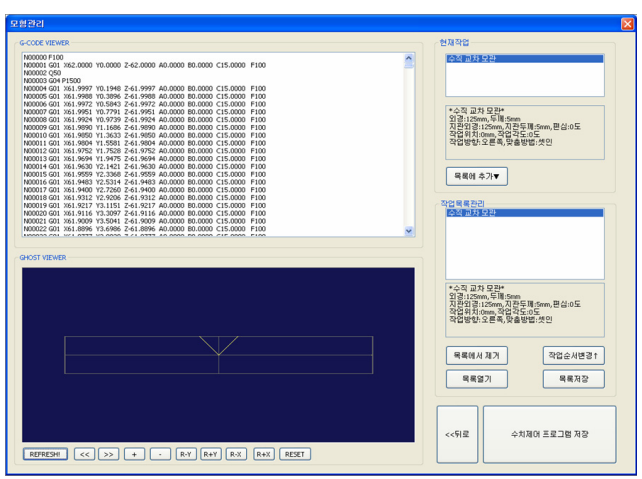

[그림 15] 절단궤적, 개선각 결정 및 ghost에 의한 절단궤적 확인 
상기의 준비 작업이 완료되어 작업자가 가공작업에 대 한 "Start"를 누르면 가공이 시작되면서 터치 패널에는 그 림16의 주 화면이 표시되며, 여기에는 툴 이송 좌표값, 각종 작업상태, 현재의 가공 궤적 등이 표시된다.

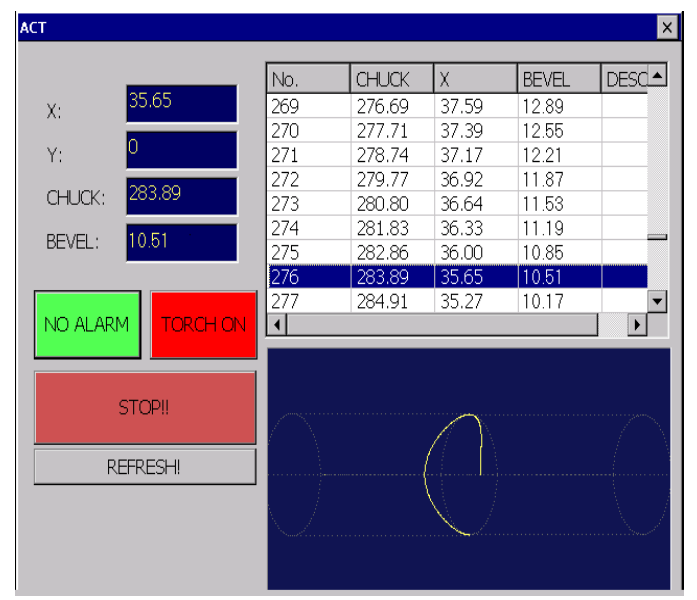

[그림 16] 실제가공시 현재 툴 좌표 값 및 절단 궤적

수직교차접합형상의 지관에 대하여 궤적절단 및 개선 가공을 한 결과는 그림 17 과 같으며, 아주 만족할만한 결 과를 얻었다.

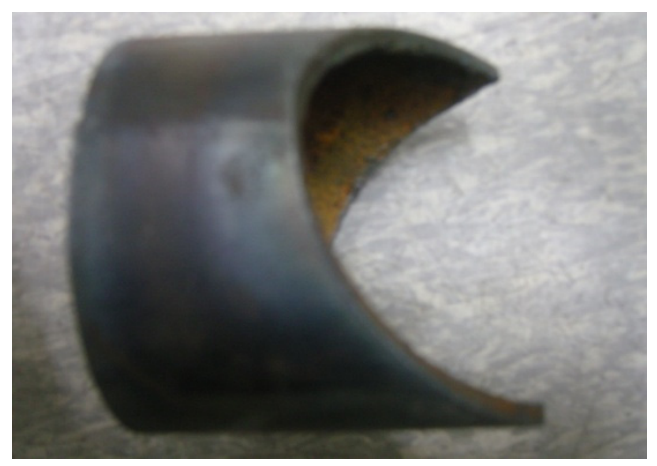

[그림 17] 수직교차접합형상(지관)의 가공 결과

\section{7. 결 론}

PLC의 위치결정제어 모듈을 사용하여 모관과 지관의 다양한 접합형상에 대하여 절단궤적을 따라서 형상절단 과 동시에 용접부 개선을 자동으로 수행할 수 있도록 동 시 3축 파이프 절단기 시스템을 개발하였으며, 그 결론을 요약하면 다음과 같다.
1. 다양한 접합형상에 대하여 모관과 지관의 접합궤적 을 수학적으로 유도하였고, 그 접합궤적에 절단폭 등을 보정하여 실제로 가공할 절단궤적을 결정하 고, 이 툴 궤적에 해당하는 CL-data를 생성하고, 또 한 CL-data의 궤적을 확인하기 위하여 ghost 기능을 수행하는 CAM 프로그램을 개발하였다.

2. 생성된 CL-data를 PLC의 위치결정제어 모듈에 로 딩하여 동시 3축의 이송을 제어하여 궤적을 따라서 형상절단과 동시에 개선을 할 수 있도록 개발하였 으며, PLC의 사용은 신뢰성과 내구성을 충분히 보 장할 것으로 본다.

3. CAM 프로그램을 내장한 터치 패널은 실제 가공작 업에 대한 모니터링과 동시에 작업에 대한 전반적 인 기능을 내장시켜 사용자가 작업하기에 매우 용 이하도록 개발하였다.

\section{참고문헌}

[1] 이욱진, 김화일, 이준우, 임근호, 노태정, "지관용 파이 프 절단기에서 개선을 고려한 절단궤적에 관한 연구", Proc. of KSME 2009 Spring Conference, pp.270 271, 2009.5.8.

[2] 이욱진, 김화일, 박순종, 유창훈, 노태정, "접합형상 인 식 자동 파이프절단기 개발", Proc. of KSPE 2009 Spring Conference, pp.855 856, 2009.6.4.

[3] 윤태호, “파이프 코스터를 이용한 파이프 트러스 자동 제작시스템 개발”, 한국과학재단, 2002.

[4] 김국환, 이명철, 이순걸, “자석식 자동 파이프 절단기를 위한 신뢰성 있는 제어기 개발", Proc. of KSPE 2002 Fall Conference, pp.1019 1022, 2002.

[5] 주영철, 엄태준, 이창훈, 공용해, 천인국, 김승우, 방재 철, "임의형상가공시스템을 위한 레이저 5 축 경사절단 기 및 궤적생성 알고리즘의 개발”, 한국산학기술학회논 문지, Vol.4, No.1, pp.1 6, 2003.

[6] 최계광, "CAD/CAM을 활용한 로터리 압축기의 사이드 블록 제작", 한국산학기술학회논문지, Vol.6, No.6, pp.555 559, 2005.

[7] T.J. Lho, D.J. Kang, A.S. Oh, J.W. Kwon, S.T. Bae, K.H. Lee, "An Implementation of the Vectorizing-Based Automation Nesting Software NST", LNCS 3981, pp.309 318, 2006.

[8] 이홍주, 강재관, "5축 레이저 절단기를 이용한 파이프 정밀 절단용 CAM 시스템 개발", Proc. of KSPE 2008 Spring Conference, pp. 325 326, 2008.

[9] 노태정, 이욱진, "6축 $\mathrm{CNC}$ 파이프 코스터 전용 $\mathrm{CAM}$ 
프로그램 구현", 한국산학기술학회논문지, Vol.10, No.9, pp.2202 2209, 2009.

노 태 정(Tae-Jung Lho)

[정회원]

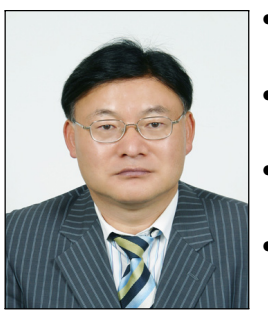

- 1984년 2월 : 부산대 기계설계 학과(공학학사)

- 1986년 2월 : KAIST 생산공학 과(공학석사)

- 1992년 8월 : KAIST 정밀기계 공학과(공학박사)

- 1986년 2월 1999년 2월 : 삼 성중공업 기전연구소(수석연구 원)

- 1999년 3월 현재 : 동명대학교 메카트로닉스공학과 부교수

<관심분야>

Mechatronics, Robotics, CNC \& CAM, 제어 및 자동화 등

\section{김 화 일(Hwa-il Kim)}

[준회원]

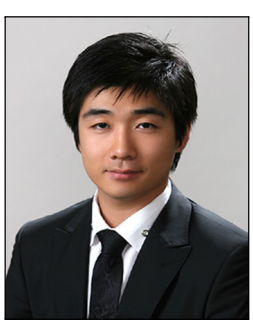

- 2008년 2월 : 동명대학교 메카 트로닉스공학과 (공학사)

- 2008년 3월 현재 : 동명대학 교 메카트로닉스공학과 석사과 정

<관심분야>

Mechatronics, PLC제어, 구조해석, CNC \& CAM 